\title{
Soil Water Studies on Oxisols and Ultisols of Puerto Rico: III. Capillary Conductivity ${ }^{1}$
}

\author{
James M. Wolf and Mathew Drosdoff ${ }^{2}$
}

\begin{abstract}
Values of capillary conductivity were calculated for the Humatas and Bayamón soils. These were found to be highly water content dependent. Using values of capillary conductivity, it was estimated that $10 \%$ of the water required for evapotranspiration might be supplied by upward water movement from the profile below the root zone.
\end{abstract}

\section{INTRODUCTION}

Wolf and Drosdoff $(3,4)$ reported previously on movement, retention, and availability of water on Oxisols and Ultisols of Puerto Rico.

This paper reports data on the capillary conductivity of the Humatas and the Bayamón soils as determined in the field. Data were not adequate to make similar calculations for the Torres and Catalina soils where rainfall, subsequent to irrigations, prevented calculation of vertical water flux.

\section{METHODOLOGY FOR FIELD DETERMINATION AND CALCULATION OF CAPILLARY CONDUCTIVITY}

Information on soils and on field and laboratory techniques can be obtained from Wolf and Drosdoff (3). Estimates of capillary conductivity were obtained in the field using the method of Richards et al. (2) and Ogata and Richards (1). Plots were instrumented with tensiometers at $7.5,30,60,90$, and $120 \mathrm{~cm}$. Undisturbed cores were taken for laboratory determinations of the relationship between soil water content and tension. Due to horizontation and textural differences, soil water content

'Submitted to Editorial Board April 25, 1975.

${ }^{2}$ Formerly Lecturer, Department of Agricultural Engineering, now with CIDIAT, Mérida, Venezuela, and Professor of Soil Science, Department of Agronomy, respectively, Cornell University, Ithaca, N.Y., in cooperation with the Agricultural Experiment Station of the University of Puerto Rico, and with the support of the U.S. Agency for International Development under Research Contract csd 2490. The authors are indebted to several people for assistance during the course of the work. Dr. Richard Fox was singularly helpful in providing logistic support. Gaston Amedée assisted greatly in both the lab and field. Drs. Levine and Bouldin willingly gave their time in reviewing this material. Many other people at Río Piedras, Corozal and the other sites gave assistance when needed. Special thanks are due to Dr. Miguel A. Lugo-López for his assistance in preparing the manuscript for publication. Lastly, the senior author acknowledges the continued support by the Agricultural Engineering Department, Cornell University, which enabled him to undertake this work. 
versus tension was found to be depth dependent. Thus the need for a specific soil water release curve for each depth was established.

In order to determine the flux of water, after irrigation the plots were covered with 6 mil polyethylene plastic. Thus, water content changes were associated only with infiltration and drainage; there was no evaporation. The assumption was made that lateral water movement with time was slight and that all water content changes occurred in a vertical downward direction. This is to say that the amount of water passing through a given point in the profile for a certain period was the sum of all the water content changes above that point in the same period. Thus, the flux for drainage at $60 \mathrm{~cm}$ will always be equal to or exceed that at $30 \mathrm{~cm}$, because all water stored and then lost from the upper part of the profile must drain through the depths below.

Flux was calculated by noting tensions $T\left(t_{1}, \dot{d}_{1}\right)$ and $T\left(t_{2}, d_{1}\right)$ in which the subscripts refer to time and depth, respectively. Water contents from the water release curves were associated with the tensions. Change in water content for a certain time and depth was assumed to be the average change in water content for a zone of soil the midpoint of which was the tensiometer. Thus, for the tensiometer at $60 \mathrm{~cm}$, water content changes were assumed to have occurred uniformly between 45 and $75 \mathrm{~cm}$. An exception existed for the tensiometer at $30 \mathrm{~cm}$ where the representative zone was considered to be from 0 to $45 \mathrm{~cm}$. Multiplying the change in water content by the vertical distance gave the amount of water passing through the bottom of the first zone. For example, a loss of $2 \%$ in water content in a day (as indicated by the tensiometer at $30 \mathrm{~cm}$ and the water release curve for $30 \mathrm{~cm}$ ) would give a flux of $0.9 \mathrm{~cm} /$ day passing through the $45-\mathrm{cm}$ depth. If during the same time interval the tensiometer at 60 $\mathrm{cm}$ had associated with it a loss of $1 \%$ in water content, the flux at $75 \mathrm{~cm}$ would be $1.20 \mathrm{~cm} /$ day $(0.90+0.30)$.

Dividing flux by hydraulic gradient gave capillary conductivity. Since capillary conductivity was associated with a hydraulic gradient between two tensiometers, and water was conducted through this zone in order to pass from the point in the profile where the flux was caluclated, capillary conductivity was established for the zone between tensiometers, i.e., 7.5 to 30,30 to 60,60 to 90,90 to $120 \mathrm{~cm}$. Capillary conductivity was linked to water content by finding an average water content (average of four values) for two depths and times. Since capillary conductivity is highly water-content dependent, time intervals were kept short for calculations when water contents were rapidly changing.

In the Humatas soil, flux of water at the $120-\mathrm{cm}$ depth on the day following the irrigation was approximately $0.75 \mathrm{~cm} /$ day. This decreased to approximately $0.12 \mathrm{~cm} /$ day 7 days after the irrigation. In the second irrigation of the Humatas soil, flux of water passing through the top 120 
$\mathrm{cm}$ of soil was $0.32 \mathrm{~cm} /$ day, 8 days subsequent to irrigation and 3 days following a heavy rainfall. Thirteen days after the irrigation ( 8 days after the rain), drainage occurred at the rate of $0.12 \mathrm{~cm} /$ day. Thus, in the absence of rainfall drainage from the profile might be expected to occur at the rate of $0.1 \mathrm{~cm} /$ day after 10 days.

\section{RESULTS AND DISCUSSION}

Values of capillary conductivity for Humatas soil are shown in figure 1. Capillary conductivities descreased in relation to the soil layers as follows: 90 to 120,60 to 90,0 to 30,30 to $60 \mathrm{~cm}$. Thus, the top $60 \mathrm{~cm}$ of the profile was least permeable and the $90-$ to $120-\mathrm{cm}$ depth, the most permeable. At the $120-\mathrm{cm}$ depth a $2 \%$ reduction in water content resulted

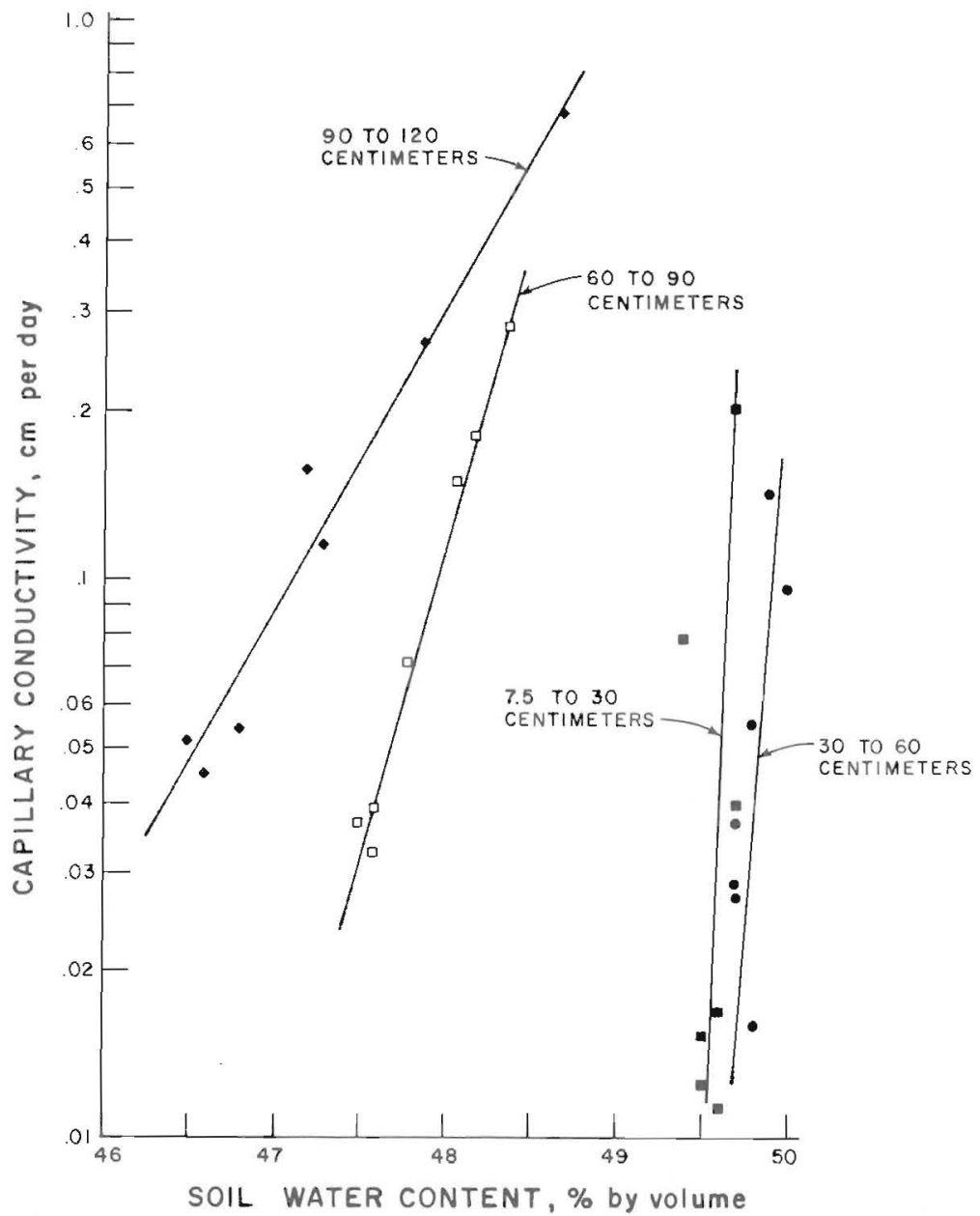

Fig. 1. - Capillary conductivity versus soil water content for Humatas clay. 


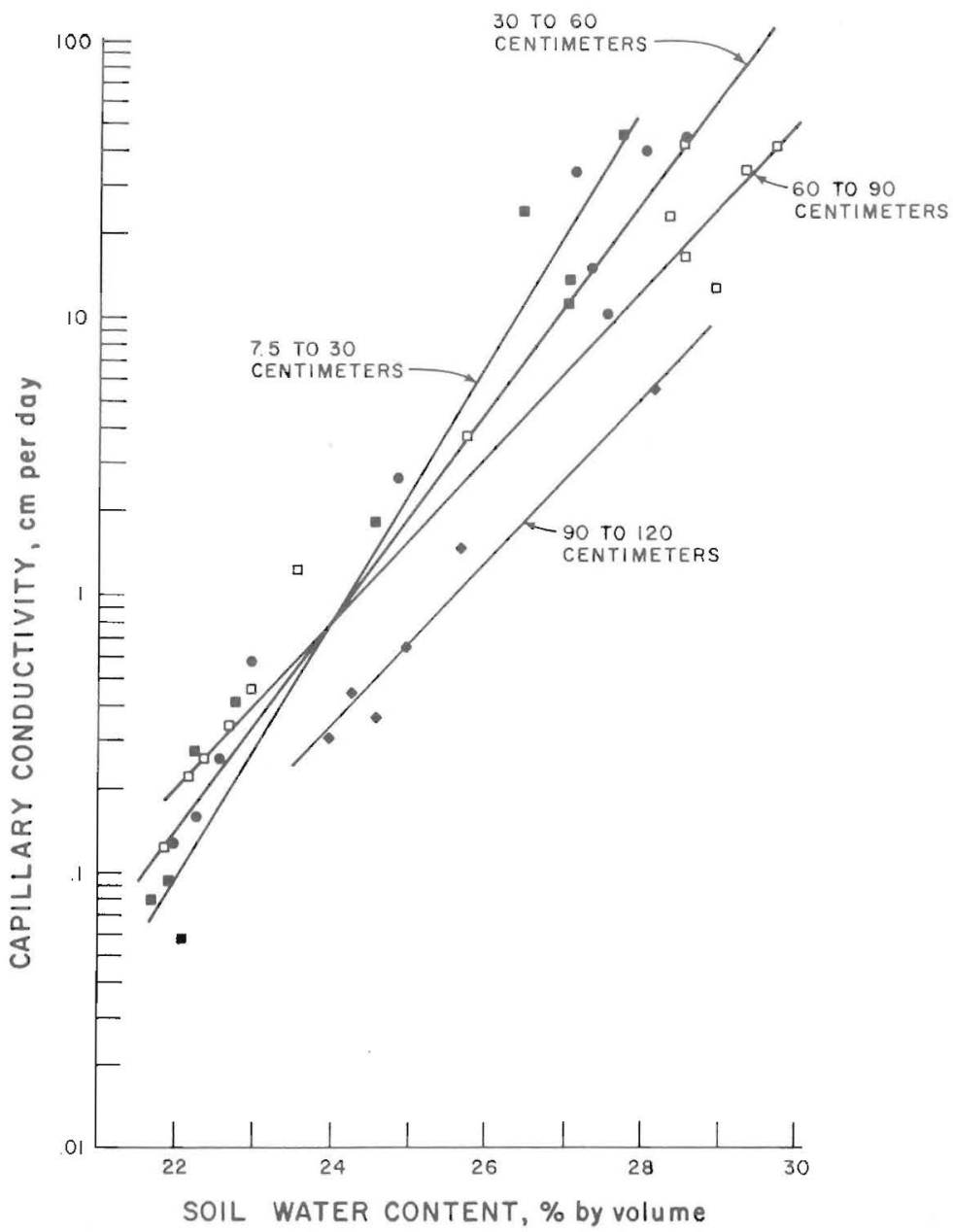

FIG. 2. - Capillary conductivity versus soil water content for Bayamón sand.

in a greater than tenfold decrease in capillary conductivity. This is an example of the great dependence of capillary conductivity upon water content. Soil water tension changes under the plastic covering were small, giving a narrow range of water content for the 0 - to $60-\mathrm{cm}$ zone. Graphed on a linear vertical axis, apparent scatter at these depths is suppressed.

Figure 1 also shows that the soil at the lower depths drained most readily and that soil from $0-$ to $60-\mathrm{cm}$ depth restricted water movement most. For the Humatas soil, the $30-$ to $60-\mathrm{cm}$ depth has been correlated with clay accumulation.

Capillary conductivity values for Bayamón soil are given in figure 2. 
Relative to Humatas soil, capillary conductivities are much greater. Capillary conductivity values for all depths are similar in accordance with the visual uniformity of the soil.

Capillary conductivity is highly water content dependent. In general, a $2 \%$ decrease in water content will result in a tenfold decrease in capillary conductivity. This relationship is somewhat less steeply sloping for Bayamón than for Humatas soil over the range of water contents observed.

Use of capillary conductivity values in conjunction with tensiometer data can provide estimates of water flux at any depth in the profile. Such information is particularly useful when data are required on the magnitude of water loss beneath the root zone due to deep percolation in irrigation efficiency studies. A specific application of the data is in estimating the magnitude of upward movement of water from a water table to supply a crop. If the top $60 \mathrm{~cm}$ of the Humatas profile were dewatered to a tension of $3 / 4$ bar (water content $=46.6 \%$ (4)) by a crop which rooted only to $60 \mathrm{~cm}$, soil water tensions below $60 \mathrm{~cm}$ of about 1/10 bar might be expected (water content $=46.7 \%$ (4)). In such a situation capillary conductivity would be on the order of $0.003 \mathrm{~cm} /$ day. Calculations reveal that upward flux of water might then be $0.06 \mathrm{~cm} /$ day. Thus, $10 \%$ of the water for evapotranspiration might be supplied from the profile below the root zone. The data can also provide estimates of nutrient loss by deep percolation once salt concentrations of the leachate are known. Unfortunately, the curves of figures 1 and 2 cannot be extrapolated with confidence to provide good estimates of capillary conductivity versus water content in drier soils.

\section{RESUMEN}

Se calcularon los valores de conductividad capilar para los suelos Humatas y Bayamón. Se encontró que estos valores dependen en alto grado del contenido de agua del suelo. Usando los valores de conductividad capilar se estimó que el $10 \%$ del agua requerida para la evapotranspiración puede ser suministrada por el movimiento ascendente del agua de aquella parte del perfil del suelo fuera de la zona de raíces de las plantas.

\section{LITERATURE CITED}

1. Ogata, G., and Richards, L. A., Water content changes following irrigation of bare-field soil that is protected from evaporation, Soil Sci. Soc, Amer. Proc. 21: 335-56, 1957.

2. Richards, L. A., Gardner, W. R., and Ogata, G., Physical processes determining water loss from soil, Soil Sci. Soc. Amer. Proc. 20: 310-4, 1956.

3. Wolf, J. M., and Drosdoff, M., Soil water studies on Oxisols and Ultisols of Puerto Rico: I. Water movement, J. Agr. Univ. P.R. 60 (3): 375-85, 1976.

4. - $\longrightarrow$, and - Soil water studies on Oxisols and Ultisols of Puerto Rico: II. Moisture retention and availability, J. Agr. Univ. P.R. 60 (3): 386-94, 1976. 